\title{
CITIZEN'S PARTICIPATION IN DECISION MAKING PROCESS THROUGH WARD SHAVA AT THE LOCAL GOVERNMENT IN BANGLADESH: A STUDY ON GOGRAM UNION IN RAJSHAHI DISTRICT
}

\author{
Sajib Kumar Roy \\ Lecturer, Department of Development Studies \\ Hajee Mohammad Danesh Science \\ \& Technology University, \\ Dinajpur-5200, Bangladesh.
}

\begin{abstract}
This paper surveys the citizen's participation in the decision making process through ward shava at the local government in Bangladesh. The study aims are to measure the citizen's participation in the decision making process by ward shava in reality. A survey method was conducted and data collected from 24 respondents from Gogram Union at Godagari Upazila in Rajshahi District. The findings of this study showed there is a very limited scope of bottom-up planning (Union Parishad to Central Government) so that local needs, priorities, and aspirations could be reflected in the macro-level planning of the country.
\end{abstract}

Keywords - local government, citizen participation, decision-making, ward shava, Bangladesh

\section{INTRODUCTION}

Citizen participation means an individual or collective action, intending to identify and address issues of public interest. Citizen participation is a process where citizens organize themselves and their goals at the grassroots level and work together through non-governmental community organizations to influence the decision-making process. Participation in decision-making means an opportunity for the citizens, Civil Society Organizations, and other stakeholders to influence the development of policies and laws that impact them. Union Parishad is the lowest tier of local government in Bangladesh. After the enactment of the Local Government (Union Parishad) Act - 2009, Union Parishad is to follow some rules for ensuring citizen's participation in the decision-making process through Ward Shava that introduces a new dimension for participatory planning and budgeting at the local level. But this process is not fully implemented at all Union Parishads in Bangladesh for various reasons such as the unwillingness of UP representatives to follow the rules, limited or less interest

\author{
Bikram Biswas \\ Lecturer, Department of Educational Administration \\ Noakhali Science and Technology University, \\ Noakhali-3814, Bangladesh.
}

of common people to participate in the decision-making process, etc. To ensure democratic practice at all levels, the concerned authorities have to ensure citizen's active participation in decision making that may indirectly influence the national policy process also. This study aims to examine the extent of citizen participation of a Ward of Gogram Union at Godagari Upazila in the Rajshahi District. The main objective of this study is to draw a comprehensive picture of citizen's participation in decision making through Ward Shava that may represent on behalf of all Union Parishads in Bangladesh. To achieve this objective, the following specific objectives have analyzed: To find out the real scenario of citizen's participation in decision making through Ward Shava at Ward level of all Union Parishads in Bangladesh. To mention the reason why common people participate or not in the decision making process. To evaluate the impact of participation in citizen services.

\section{A. Statement of the Problem -}

In the context of Bangladesh, almost all the policies are taken by top-level management especially follow the topdown approach where the common people have no option to take part in that process. It is impossible to draw a comprehensive picture that reflects the needs of common people without their citizen active participation in the decision-making process. According to the Local Government (Union Parishad) Act - 2009, two Ward Shava must be organized in a year at each ward of a union by ensuring $20 \%$ attendance of total voters from that ward. Without the involvement of grass-root level people into the decisionmaking process, it is not possible to ensure community development because local people know their needs very well. If they can express their views in any public meeting or inform about their demands, it will be easy to take any policy for the betterment of common people. After the enactment of the 


\section{International Journal of Engineering Applied Sciences and Technology, 2020}

Vol. 5, Issue 1, ISSN No. 2455-2143, Pages 702-710

Published Online May 2020 in IJEAST (http://www.ijeast.com)

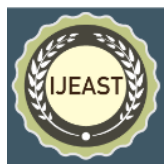

Local Government (Union Parishad) Act - 2009, almost 9 years have been passed. But the real scenario is not changed or limited changed. Bodiul Alam Majumdar, Secretary of SUJON, told that - local level participation has to ensure in local government agencies - at a seminar on 'National Budget and Local Government' held in National Press Club 2013 published by a national daily (Prothom Alo: December, 2013).

Citizen's involvement in the decision-making process or participatory planning is very crucial for community development. If we want to ensure participatory planning and budgeting that contributes to the development of the whole society as well as the country, the main task is to include mass people in the decision-making process and provide opportunities to express their views. That's why it is essential to ensure citizen's participation in the decision-making process through Ward Shava for the advancement of society. Citizen's involvement in decision making process or participatory planning is very crucial for community development. If we want to ensure participatory planning and budgeting that contributes the development of whole society as well as country, the main task is to include mass people in decision making process and provide opportunities to express their views. That's why it is essential to ensure citizen's participation in decision making process through Ward Shava for the advancement of the society.

\section{LITERATURE REVIEW}

Begum (2012), in her research paper namely "Women's participation in union parishads: a quest for a compassionate legal approach in Bangladesh from an international perspective", has focused on the socio-cultural scenario of Bangladesh \& legal framework to women's political participation, records of women member's participation in Union Parishad, and less perspective for women member's effective participation in the decision-making process. Besides, she also suggested some recommendations to increase women's participation in Union Parishad. But she only focuses on women's participation rather than all citizens' participation in the decision-making process.

Haruta \& Radu (2009) published a research paper namely "Citizen participation in the decision making process at local and county levels in the Romanian public institution". Their research project aimed to find out the policy actors of public institutions, degree of citizen participation in making decisions, resistance from citizens to make certain decisions, the importance of the information provided by citizens for public officials when making decisions, and major constraints in public policy formulation process. Though they discussed the citizens' participation in the decision-making process at public institutions, but not mentioned the citizen's participation in the decision-making process with elected representatives at the local level.

Irvin \& Stansbury (2004) conducted research namely "Citizen Participation in Decision Making: Is it worth the effort?" where they mentioned the advantages \& disadvantages of citizen participation in government decision making and ideal \& non-ideal for citizen participation. Here they pay more attention to citizens' participation in government decision making, but this research paper focuses on a global perspective. They didn't say anything about citizen participation in decision making at the local level separately.

Renn et al. (1993), in their writings namely "Public participation in decision making: A three-step procedure", emphasized on citizens' participation in the decision-making process through citizen panels where the members of citizen panels are randomly selected from directly and indirectly affected citizens in an organization. But they ignored the view of those who are not affected by the organization. They had to seem that, the view of non-affected persons is also important for an organization. For that reason, to draw a comprehensive picture of citizens' participation in the decision-making process, a study on a selected topic is to be helpful.

Ireland \& Vincent (1974), in their research paper namely "Citizen Participation in Decision Making - a Challenge for Public Land Managers", identified major challenges to public land managers for citizens' participation in the decisionmaking process and introduced issues surrounding participation in land-use decisions by citizen groups. But they have not mentioned issues for community development through citizens' participation in the decision-making process. That is why the selected study is needed to mention the reasons for citizens participated in the decision-making process or not.

\section{A. Decision Making-}

Decision-making is a process of selection and the aim is to select the best alternative. It can be regarded as the cognitive process resulting in the selection of a belief or a course of action among several alternative possibilities. Decisionmaking is the study of identifying and choosing alternatives based on the values and preferences of the decision-maker. Decision-making is one of the central activities of management and is a huge part of any process of implementation. Decision-making involves a conscious choice or selection of one or more behavior alternatives from among a group of two or more behavior alternatives (Tannenbaum et al., 2013). Decision-making in government is a plural activity. One individual may pronounce the decision but many a part of the political system (Hudson,1955).

By integrating multi-dimensional aspects of decision making into a practical procedure, Renn et al. (1993) have mentioned a participatory model that assigns specific tasks to different groups in society. The model entails three consecutive steps:

Step 1: Identification and selection of concerns and evaluative criteria;

Step 2: Identification and measurement of impacts of the different decision options; and 


\section{International Journal of Engineering Applied Sciences and Technology, 2020}

Vol. 5, Issue 1, ISSN No. 2455-2143, Pages 702-710

Published Online May 2020 in IJEAST (http://www.ijeast.com)

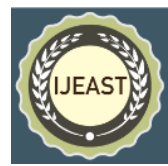

Step 3: Aggregation and weighting of expected impacts by randomly selected citizens and elicitation of citizen's preferences.

In this study, the term decision making describes the ability of common people to select their needs gradually based on priority for their lives and livelihoods.

\section{B. Participation -}

Participation is one of the most fundamental elements of governance and a key indicator for assessing fairness and quality of the government. Good governance depends on the maximum realization of stakeholder participation in society (Vigoda-Gadot \& Mizrahi, 2008). Begum (2012) has mentioned that quality participation can be ensured by requiring the incorporation of women members in decision making. A compassionate approach is developed for the workplace to accommodate exceptional gender-centric concerns in Union Parishads by fostering a relationship in which men and women see each other as interdependent and interconnected. Irvin and Stansbury (2004) argued that increased community participation in government decision making provides many important benefits. Sherry Arnstein (1969) discusses eight types of participation in A Ladder of Citizen Participation. Often termed as "Arnstein's ladder", these are broadly categorized as:

Citizen Power: Citizen Control, Delegated Power, Partnership. Tokenism: Placation, Consultation, Informing. Nonparticipation: Therapy, Manipulation.

Arnstein (1969) also defines citizen participation as the redistribution of power that enables the have-not citizens, presently excluded from the political and economic processes, to be deliberately included in the future. Robert Silverman (2005) expanded on Arnstein's ladder of citizen participation with the introduction of his "citizen participation continuum." In this extension to Arstein's work, he takes the groups that drive participation into consideration and the forms of participation they pursue. Consequently, Silverman's continuum distinguishes between grassroots participation and instrumental participation.

Fung (2006) presents another classification of participation based on three key questions: Who is allowed to participate, and are they representative of the population? What is the method of communication or decision-making? And how much influence or authority is granted to the participation? The right of participation in decision making in social, economic, cultural, and political life should be included in the nexus of basic human rights. Citizenship as participation can be seen as representing an expression of human agency in the political arena, broadly defined; citizenship as rights enables people to act as agents (Lister, 1998). In this study, the term participation refers to civic engagement as well as local people involved in decision making through local level institution especially Union Parishad.

\section{Citizens' Participation -}

Citizen participation means an individual or collective action, with the aim of identifying and addressing issues of public interest. Citizen participation is a process where citizens organize themselves and their goals at the grassroots level and work together through non-governmental community organizations to influence the decision-making process. Participation in decision-making means an opportunity for the citizens, CSOs and other stakeholders to influence the development of policies and laws that impact them. (http://www.kcsfoundation.org/?page=2,63). Renn et al (1993) have given a conceptual model for participatory decision making and urged for public participation in the decisionmaking process - in their writings namely Public Participation in decision making: A three-step procedure.

Mazmanian and Nienaber (1979) have emphasized public involvement in the decision-making process in their writings namely Can Organizations Change? Environmental Protection, Citizen Participation and The Corps of Engineers published from Washington D.C. Day (1997) has mentioned that Citizen Participation in public affairs "seems to hold a sacrosanct role in U.S. political culture. A central tenet of the enthusiasm accorded to citizen participation is the belief that citizen involvement in a Jeffersonian democracy will produce more public-preference decision making on the part of administrators and a better appreciation of the larger community among the public (Stivers, 1990; Oldfield, 1990).

In this study, the term citizen's participation refers to the situation in which all men and women have a voice in decision making through local level institution especially Union Parishad that represent their intention.

\section{Citizens' Participation in Decision Making -}

Citizen participation, therefore, should be used to mean the acknowledgment and practice of inherent freedoms and liberties within a society and the used those freedoms by every citizen decide whether directly or indirectly on matters affecting them legitimately and constructively. It implies freedom of association, freedom of speech, respect of human rights and liberties, and the ability to influence decision making and enhance public accountability and responsiveness. From the above discussion, it is clear that citizens' participation in decision making means the ability of common people to participate in making any decision especially in the matter of selecting their needs/demands. It also reveals that power/access to mass people by which they may be able to decide the needs that affect their life. In this study, the term citizens' participation in decision making describes the ability of local people to raise their vocal especially active 


\section{International Journal of Engineering Applied Sciences and Technology, 2020 \\ Vol. 5, Issue 1, ISSN No. 2455-2143, Pages 702-710 \\ Published Online May 2020 in IJEAST (http://www.ijeast.com)}

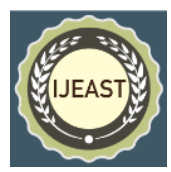

participation at the time of making any decision or mentioning the local needs.

\section{E. Ward Shava -}

Union Parishad is the lowest tier of the Local Government of Bangladesh. A Union consists of nine wards. According to the Local Government (Union Parishad) Act - 2009, there is a provision for organizing 'ward shava' twice in a year of each ward. The term 'ward shava' denotes that shava which is organized twice in a year within the jurisdiction of a ward where $20 \%$ voters (including both male $\&$ female) must be attended.

\section{F. Analytical Framework -}

\begin{tabular}{|c|c|}
\hline \multicolumn{1}{|c|}{ Dependent Variable } & \multicolumn{1}{|c|}{ Independent Variable } \\
\hline$>\begin{array}{l}\text { Citizen's participation } \\
\text { in decision making }\end{array}$ & $>$ Access to Ward Shava \\
$>\begin{array}{l}\text { Ability to share an opinion } \\
\text { (participate) in Ward } \\
\text { Shava }\end{array}$ \\
$>\begin{array}{l}\text { Understanding of decisions } \\
\text { taken at Ward Shava }\end{array}$ \\
\hline
\end{tabular}

From the above mentioned analytical framework especially variable chart (dependent and independent both), it is clear that, citizens' participation in decision making is possible only when the local people having access to ward shava, ability to share opinion in ward shava and ability to understand the decision taken at ward shava; and i. e., the main theme of this study.

\section{RESEARCH METHODOLOGY}

The research methodology is such a process by which research objectives are acquired. It denotes the detailed framework of the unit of analysis for collecting data, gathering techniques, sampling focus, and interpretation strategy, and analysis plan. There are two types of research methods, one is a quantitative research and another is qualitative research. Quantitative research is based on the measurement of quantity or amount of data. On the other hand, qualitative research has conversed with the qualitative phenomenon. Qualitative research is important to discover the underlying motives of human behaviors (Kothari, 1985:4).

To fulfill the objectives of this research, the researcher has followed the survey method for the collection of original data. The survey method is the most widely accepted in social science research. It is probably the best method available to the social scientists interested in collecting original data to describe a population too large to observe directly. Surveys are widely used to collect information and observation over time. It refers to the technique of collection of data through interviews, questionnaires, and secondary sources in the light of a specific research objective.

The researcher has selected survey method because of the following specific advantages:

The Social survey is more reliable for collecting data and well-organized information about the research or particular problem. Through social survey, a researcher or an investigator can be able to contact directly with the people from whom he collects the information. In this process, the new facts of life can be gathered based on which new theories can be developed. It is an excellent vehicle for the measurement of attitudes and orientations prevalent within a large population. Public polls are well-known examples of this method. So, the researcher has used the survey method in this research for data collection.

\section{A. Methods of Data Collection-}

There are two major approaches to gathering information about a situation, person, problem or phenomenon. Sometimes, the information required is already available and need only be extracted. However, there are times when the information must be collected. Based upon these broad approaches to information gathering, data are categorized as: secondary data; and primary data. Information gathered using the first approach is said to be collected from secondary sources, whereas the sources used in the second approach are called primary sources. Primary sources provide first-hand information and secondary sources provide second-hand data (Kumar, 2007).

\section{B. Data Collection Techniques-}

For collecting data, the following methods have been used-

Interview: In this research, primary data have been collected through a questionnaire as well as interviewing methods. Generally, there are two types of questions used in the questionnaire method and i. e., (i) Open-ended question and (ii) Close-ended question. There are some reasons for selecting these two types of questions-

Only closed-ended question is not sufficient for collecting complete data. For collecting the respondent's opinions, the researcher has followed the open-ended question, in addition, closed-ended questions. By using these two types of questionnaires, the researcher has been able to collect more information from respondents. So, the researcher has decided to follow both types of questions in this research. For 


\section{International Journal of Engineering Applied Sciences and Technology, 2020 \\ Vol. 5, Issue 1, ISSN No. 2455-2143, Pages 702-710 \\ Published Online May 2020 in IJEAST (http://www.ijeast.com)}

collecting primary data, the researcher has selected 24 citizens as sample from that Ward based on income especially -

Lower class: Monthly income (maximum Tk. 5000)

Middle class: Monthly income (Tk. 5100 - Tk. 10000)

Upper class: Monthly income (more than Tk. 10000).

The criteria of higher, middle and lower class people has mentioned on the basis of study area's socio-economic condition. The researcher has also interviewed two ward members (including both male and female) of that ward for making a correlation of common people and service providers as well as Union Parishad functionaries.

\section{Documentation}

For secondary data, different sorts of documents have examined including previous research reports, books, journals, magazines and newspapers.

\section{Unit of Analysis}

In social research, there is no limit to what or who can be studied or what will be the unit of analysis. Basically, the unit of analysis is divided into individual, groups, organizations, social interactions, social artifacts, etc. Social researchers tend to choose individual as their unit of analysis (Babbie, 2007). In this study, the inhabitants of Ward no. 4 of Gogram Union at Godagari Upazila in Rajshahi District have been selected as the unit of analysis.

\section{E. Data Analysis}

If some factors or conditions go favorable with the new strategy adopted by the organization, there is more chance for that organization to work well. So it is needed to find out how individuals at the organizational level perceive the chance to participate in making any decision, and how their perception and understanding in turn affect the decision-making process through 'ward shava' at Union Parishad level. By testing this into consideration the main focus is confined to analysis on how those factors affect the rural people as well as citizens' participation in the decision-making process.

\section{RESULTS AND FINDINGS}

\section{A. Perception about 'ward shava'}

The perception about 'ward shava' is different from class to class especially among the people of the higher, middle, and lower class. The people of the lower class have no conception about 'ward shava'. A lower-class respondent namely Bimoli Mondol (55) mentions that 'I have never heard about ward shava', where Sree Ramchandra Barua (46) asks that what is ward shava? But the scenario is a little bit better among the respondents of middle class. Only $12.5 \%$ middle class respondents have the idea about ward shava, where this ratio is $37.5 \%$ among the higher class respondents. The ratio of perception about ward shava among respondents of different classes is shown by the following table:-

Table 1: Perception about ward shava

\begin{tabular}{|c|c|c|c|c|c|}
\hline Class & Number & $\begin{array}{c}\text { Have } \\
\text { perception }\end{array}$ & $\%$ & $\begin{array}{c}\text { Have } \\
\text { not }\end{array}$ & $\%$ \\
\hline Lower & 8 & 0 & 0.0 & 8 & 100.0 \\
\hline Middle & 8 & 1 & 12.5 & 7 & 87.5 \\
\hline Higher & 8 & 3 & 37.5 & 5 & 62.5 \\
\hline Total & 24 & & 16.7 & & 83.3 \\
\hline
\end{tabular}

From the above mentioned table, only $16.7 \%$ respondents have perception about ward shava among all respondents, while $83.3 \%$ have not. But the women are lagging behind in this issue. It's a matter of great upset that, among all women respondents especially lower, middle \& higher class, not a single one has idea about ward shava. Kamrunnar (27), a higher class respondent, states that, 'No one, neither Union Parishad officials nor representatives of any voluntary organization, informs them about ward shava'. The perception about ward shava of women respondents is given by the following table:-

Table 2: Women's perception about ward shava

\begin{tabular}{|c|c|c|c|}
\hline Class & Number & Have perception & Have not \\
\hline Lower & 4 & 0 & 4 \\
\hline Middle & 4 & 0 & 4 \\
\hline Higher & 4 & 0 & 4 \\
\hline
\end{tabular}

\section{B. Attendance at ward shava or not}

The attendance rate among all respondents at ward shava is frustrating and varies from class to class. Truly speaking, it is not yet possible to include all classes of people at ward shava because of chairman, members' especially Union Parishad officials' unwillingness to involve all classes of people at ward shava as well as the decision-making process. Here party politics, muscle power, and nepotism play a vital role. Because ward shava is not frequently organized by the concerned authorities especially ward members; and if organizing, almost all attendance comes from ward member's party, relatives, and rural elite. In this case, lower or middleclass people has no or limited access to participate at ward shava especially in the decision making process, because in most times they have no enough/adequate information about 


\section{International Journal of Engineering Applied Sciences and Technology, 2020 \\ Vol. 5, Issue 1, ISSN No. 2455-2143, Pages 702-710 \\ Published Online May 2020 in IJEAST (http://www.ijeast.com)}

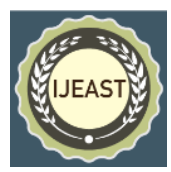

the place, time of ward shava, and the overlooking role of Union Parishad officials is responsible for this. The attendance rate is quite low among the respondents of lower class and women respondents of all classes. Except for Jesmin Aktar (30) and Mst. Shahida Begum (38), both are higher class respondents, no interviewed women respondents among all, have attended at ward shava, but they had no active participation in making any decision. Ward Member Shajamal Hossain (60) mentions that 'generally women are busy with their household chores. For that reason, they don't come'. He also argues that 'if the guardian, as well as husband of a family attends ward shava, it is not needed to attend at ward shava of the female member of that family'. By this statement, he has neglected the views or vocal of women society and compelled us to remind the exercise of patriarchic society. But the picture is different among the male respondents in terms of attending ward shava, where the higher class people get more attention than the other classes. It is shown by the following chart:-

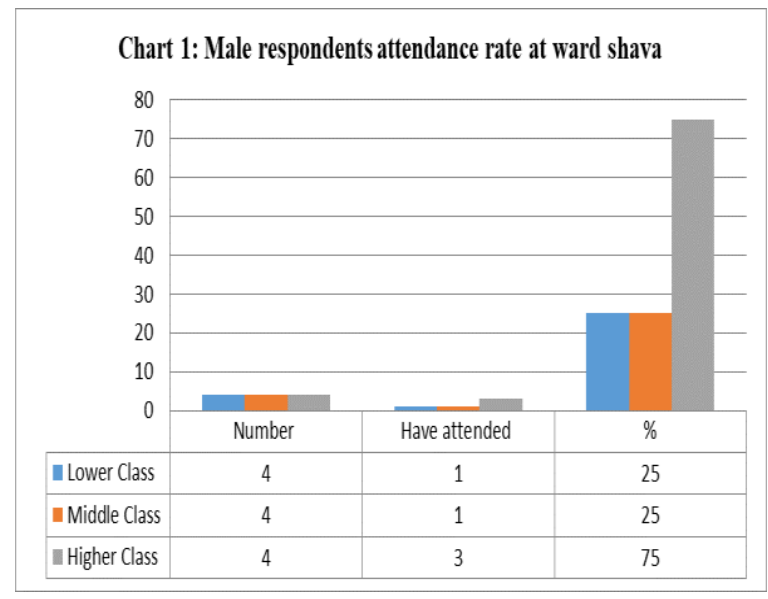

But the overall attendance rate of all respondents including both male and female is not satisfactory. It is shown by the following chart: -

Chart 2: Attendance rate among all respondents at ward shava

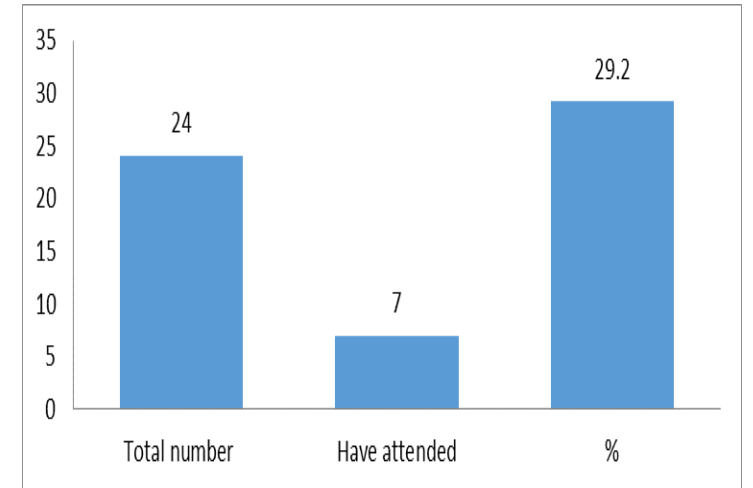

From the above mentioned chart, only $29.2 \%$ respondents have attended at ward shava. In conversation with Shajamal Hossain (60), member of Gogram Union Parishad for ward no. 4, a question thrown to him that what's the reason for low attendance at ward shava. In reply, he told that, 'lack of awareness among the local people is responsible for low attendance, but we are trying to involve local people in decision making process as much as possible'. The statement of ward member is vice-versa with the statement of common people especially those lives from hand to mouth. Sunal Toppo (28), a lower class respondent, mentions that, 'ward member never calls them for attending ward shava, in fact, without election session we have no value to him. For that reason, we poor people busy with our task, because if we remain a day without food, no one asks that have we eaten yet'. In addition, Kodbanu (72), also a lower class respondent, states that, 'she has never heard about the meeting namely ward shava organized by ward member in her entire life'. Furthermore, Sree Sores Nal (25), a middle class respondent, regrets that, "we have no value because of our poor condition as well as socio-economic condition'. Because lower and middle class respondents are treated almost same by the Union Parishad officials. But Julita Kisku (32), women member of Gogram Union Parishad for reserved seat of ward no. 4, 5 \& 6 , mentions that, after/on supporting/considering her own-side, 'I personally try to disseminate information about ward shava among all the people in my jurisdiction, but it is not wellenough/adequate to inform all the people about ward shava'. The Union Parishad representatives only try to maintain good term with those who are rurally/locally influential person especially rural elite or higher class respondents. Md. Mujtoba Kamal (45), a higher class respondent, states that, "ward member informs and invites him about any meeting or open discussion related to local development organized by Union Parishad'. But the real fact is that, in spite of having Union Parishad officials' unwillingness and indifference to their duties, the income level as well as socio-economic condition of common people, lack of awareness and education, mandatory task for maintaining livelihoods also hinder the attendance as well as participation at ward shava. If it is possible to raise awareness among the rural people and fully educate them, the present scenario especially attendance as well as participation rate of common people in decision making process through ward shava will be changed positively.

\section{Participation scenario in decision-making process among all classes of people through ward shava}

Although very few people from lower and middle class can participate in ward shava as well as decision-making process, they can't express their views or raise their vocal in that meeting. Especially they have physical appearance only of that meeting nothing else. Theoretically, it is indicated that, for making any decision at Union Parishad level related to local 
development, it is mandatory to include all classes of people in decision making process through ward shava and pay serious attention to the needs, views, and expectations of socially disadvantaged groups, especially the poor, vulnerable and excluded groups. But the real scenario is different. It is shown by the following table:-

Table 3: Difference between participation or physical appearance and active participation

\begin{tabular}{|c|c|c|c|c|}
\hline Class & $\begin{array}{c}\text { Number of } \\
\text { Respondents }\end{array}$ & $\begin{array}{c}\text { Participated } \\
\text { at Ward } \\
\text { Shava }\end{array}$ & $\begin{array}{c}\text { Raise their } \\
\text { Vocal / } \\
\text { Active } \\
\text { Participation }\end{array}$ & $\%$ \\
\hline Lower & 8 & 1 & 0 & 0 \\
\hline Middle & 8 & 1 & 0 & 0 \\
\hline Higher & 8 & 5 & 3 & 60 \\
\hline
\end{tabular}

From the above-mentioned table, the lower and middle-class respondents have no active participation in decision-making process through ward shava, where this ratio is $60 \%$ (including both male and female) among the respondents of higher class. It shows that the people with low income or little more have no chance to express their views in decision making through ward shava. Besides, the important issue is that the male respondents from higher class can raise their vocal easily in decision-making process through ward shava and the ratio is amazing which is shown by the following table:-

Table 4: Active participation rate among all male respondents

\begin{tabular}{|c|c|c|c|}
\hline Class & $\begin{array}{c}\text { Participated } \\
\text { at Ward } \\
\text { Shava }\end{array}$ & $\begin{array}{c}\text { Raise their } \\
\text { Vocal / Active } \\
\text { Participation }\end{array}$ & $\%$ \\
\hline Lower & 1 & 0 & 0 \\
\hline Middle & 1 & 0 & 0 \\
\hline Higher & 3 & 3 & 100 \\
\hline
\end{tabular}

From the above-mentioned table, the active participation rate of male respondents of a higher class is $100 \%$, where the male respondents of the middle and lower class have no active participation. Union Parishad functionaries' vice-versa attitude is responsible in this case because at the same time they maintain good relations with higher class people as well as rural elite, where negligence or negative attitude to the lower or middle-class people are shown by them. For that reason, although anyone from the lower or middle class gets chance to express his/her views at ward shava, which is made for maintaining formality only. Because the demands mentioned by lower or middle-class people are not shortlisted. Sunlal (52), a middle-class respondent, states that 'the Union Parishad functionaries have no time to listen about our demands, so how we mention our demand'. Babi Murmu (26), also a middle-class respondent, mentions that 'without election period the chairman or ward members always try to avoid us'. Besides, poor people have no chance to inform Union Parishad functionaries about their demands. For that reason, it is irrelevant for poor people to ask Union Parishad functionaries about why their demands are not shortlisted. But the respondents from higher class confess that they can mention their demands at ward shava, provide suggestions to Union Parishad functionaries related to local development and ssk Union Parishad officials that why their demands are not hortlisted. Md. Abul Basar (40), a higher class respondent, tates that 'ward members (both male and female) invite me at any meeting organized by Union Parishad and pay serious attention to my demands and suggestions. I can also ask ward members if my demands are not shortlisted'.

Besides, the rural elite can easily express their views in decision-making process through ward shava and influences decision making. Sree Ramchandra Barua (46), a lower-class respondent, states that, 'the people like me who come from poor class are always neglected or overlooked in all kinds of Union Parishad matter in comparison with higher class people'. He also mentions that the speech of ours has no value'. Besides, Bandona Maddi (23), a middle class respondent, states that the Union Parishad representatives only pay attention to the views of rural elites who helps them (member/chairman) at the time of election by providing political support'. Boiddonath (44), a lower class respondent, argues that 'the Union Parishad representatives seem that there is no need to know about the views of lower-class people. For that reason, they (Union Parishad officials) are disinterested to include/involve poor people in decision-making process through ward shava'. So it is clear that from the abovementioned statement, locally/rurally influential person especially rural elite, local leaders as well as parties, Union Parishad's chairman/member's relatives and gangs enjoy unlimited flexibility to express their views in decision-making process through ward shava and influences the decisions taken at ward shava, where the real beneficiaries especially poor people are overlooked and not able to express their views. It's a matter of great upset that, poor people are ignored almost everywhere. But it is impossible to develop rural Bangladesh by excluding poor groups as well as lower-class people, because the sufferer best knows about their emergency needs.

\section{Findings}

At the time of interviewing people as well as the target group of this study and consulting with various persons at Union 


\section{International Journal of Engineering Applied Sciences and Technology, 2020 \\ Vol. 5, Issue 1, ISSN No. 2455-2143, Pages 702-710 \\ Published Online May 2020 in IJEAST (http://www.ijeast.com)}

Parishad level, the following findings have got the attention of the researcher: -

In practice, there is the very limited scope of bottom-up planning (Union Parishad to Central Government) so that local needs, priorities, and aspirations could be reflected in the macro-level planning of the country. Citizens' participation in decision making through 'ward shava' at Union Parishad level is going through its beginning session yet because of lack of publicity and awareness among common people, the unwillingness of Union Parishad officials, noneducation/illiteracy, etc. hinder the mass people to participate in decision-making process through 'ward shava'. 'Ward shava' is almost nothing without the 'eye-wash or brain-wash' of common people.

Despite having formally approved mechanism of project identification and management at the union level, development projects are determined by the influence of local leaders instead of popular need. All major decisions about budget preparation, tax collection and assessment, construction work, judicial matters, and agricultural development are predetermined by Chairman and influential Union Parishad members before the general meeting as well as 'ward shava'. 'Village Matbars' or local leaders and local elites such as school teachers, businessmen take interest in Union Parishad matters and participate in its activities.

It is limited or almost no scope for participation either by the selected people or common people in Union Parishad's decision making as well as in the management and supervision of Union Parishad's affairs (For example, Dinesh Chandra, a person of the indigenous community, is a ward committee member, but he doesn't know about his duties. According to him, 'Ward Member has included his name for the fulfillment of ward committee list'. Besides, he has mentioned that, he is bound to be liable to their own ward's member Shajamal Hossain because of his (ward member) muscle power like other poor or vulnerable people of their community). Theoretically, the existing mode and mechanism of citizen's/people's participation at Union Parishad are adequate and effective enough. But, Poverty, information gap about Union Parishad activities, information block created by the vested powerful group, professional burden, and financial problems are some of the important factors that act as obstacles to citizen's participation in the decision- making process.

\section{RECOMMENDATION AND CONCLUSION}

\section{A. Recommendations}

Based on the above mentioned findings, the following recommendations, set by the researcher, may be implemented to overcome these obstacles: -
'People are the best judges of how their lives and livelihoods will be improved and selection of their immediate needs' - it is essential to motivate/encourage Union Parishad officials to work based on the above-mentioned theme. Because if they (UP officials) pay attention to mass people's needs/decision, citizens' participation in decision making will be ensured. Wide-spread publicity on/about the importance of citizens' participation in decision-making process has to be ensured for ensuring citizens' engagement.

Raising awareness among common people that they have the right to participate in making any decision related to Union Parishad/local development through 'ward shava' and to raise their vocal about any local interest issue through information sharing, meeting, seminar or workshop. A short-range payment system for the participants, especially for those who are vulnerable or poorest of the poor, from the Union Parishad that will be motivated them about the participation because a large number of rural people (such as day labourer, rickshaw puller, street hawker etc.) lives from hand to mouth. To make sense the common people that it's (participate in decision making) not their burden, it's their right/duty. Educate all the people of the rural level because education is one of the necessary criteria for the advancement or development of a society.

Mitigation of corruption, nepotism, muscle power of rural elite or local leaders, political parties influence at the time of service delivery and decision-making process. Mitigation of the influence of cash in Union Parishad election because of more cash expense in election force more corruption that results in limited or no scope for mass people to participate in decision making. Because of the Union Parishad officials take every decision on consensus and implement that decision through public involvement, they will have no chance for making any corruption. Make available room for ensuring accountability of Union Parishad representatives to the common people like as 'budget shava' because 'budget shava' is held once in a year. Because if the mass people can question the Union Parishad representatives spontaneously about their query and get answer, it will ensure vocal raising of common people as well as participation. In practice, to motivate Union Parishad officials for making all decisions related to local development such as budget preparation, infrastructural development etc. based on consensus.

\section{$B$. Conclusion}

After the birth of Bangladesh as an independent nation, every successive government took attempts to change the structural aspects of urban local government bodies. But they ignored the importance of functional aspects. In doing so, they have introduced several changes in the urban local government system. But the process of evolution of the local government system in Bangladesh has shown that the rise and fall of the 


\section{International Journal of Engineering Applied Sciences and Technology, 2020 \\ Vol. 5, Issue 1, ISSN No. 2455-2143, Pages 702-710 \\ Published Online May 2020 in IJEAST (http://www.ijeast.com)}

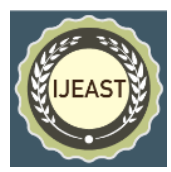

local government has dependent on political perceptions and attitudes of successive regimes. In this study, the researcher mainly focuses on citizen's participation in decision making through 'ward shava' at Union Parishad level of rural Bangladesh. The researcher has also identified some constraints/limitations that hinders mass people to participate in making a decision especially in the issue of local development or selecting local needs and provided some recommendations based on above-mentioned findings as well as practical observation in some cases at the time of collecting primary data which may be testified or applied in the real field for promoting the citizen's participation in the decisionmaking process at the local level. In the end, it may be said that the real scenario is changing but slowly and that's the matter of hope for the inclusion of local people in the decision-making process at Union Parishad level of rural Bangladesh.

\section{REFERENCE}

[1] Arnstein, S. R. (1969). A ladder of citizen participation. Journal of the American Institute of planners, 35(4), 216224.

[2] Babbie, E., (2004). The practice of social research, 10th ed. Singapore: Thomson Asia Pte. Ltd.

[3] Begum, A. (2012). Women's participation in Union Parishads: A quest for a compassionate legal approach in Bangladesh from an international perspective. South Asia: Journal of South Asian Studies, 35(3), 570-595.

[4] Day, D. (1997). Citizen participation in the planning process: An essentially contested concept?. Journal of planning Literature, 11(3), 421-434

[5] Fung, A. (2006). Varieties of participation in complex governance. Public administration review, 66, 66-75.

[6] Haruta, C., Radu, B., \& Liviu, R. A. D. U. (2009). The ruling political class? A theoretical analysis of the political actors' role as major decision makers in the context of the politico-administrative relations. Transylvanian Review of Administrative Sciences, 5(27), 71-88.

[7] Irvin, R. A., \& Stansbury, J. (2004). Citizen participation in decision making: Is it worth the effort?. Public administration review, 64(1), 55-65.

[8] Irland, L. C., \& Vincent, J. R. (1974). Citizen participation in decision making: A challenge for public land managers. Journal of Range Management, 182-185.

[9] Kothari, C. R. (2004). Research methodology: Methods \& techniques, $2^{\text {nd }}$ ed. New Delhi: New Age International Publishers.

[10] Kumar, R., (2007). Research methodology, $2^{\text {nd }}$ ed. New Delhi: Derling Kindersley (India) Pvt. Ltd.
[11] Lister, R. (1998). From equality to social inclusion: New labour and the welfare state. Critical social policy, 18(55), 215-225.

[12] Mazmanian, D. A., \& Clarke, J. N. (1979). Can organizations change?. Brookings institution.

[13] Oldfield, A. (1990). Citizenship and community: Civic republicanism and the modern world. Routledge.

[14] Prothom-Alo (a national daily of Bangladesh), Editor: Motiur Rahman; 52 Motijheel Commercial Area, Dhaka 1000. (www.prothom-alo.com)

[15] Renn, O., Webler, T., Rakel, H., Dienel, P., \& Johnson, B. (1993). Public participation in decision making: A threestep procedure. Policy sciences, 26(3), 189-214.

[16] Seckler-Hudson, C. (1955). Organization and management: Theory and practice. American University Press.

[17] Silverman, R. M. (2005). Caught in the middle: Community development corporations (CDCs) and the conflict between grassroots and instrumental forms of citizen participation. Community Development, 36(2), 3551 .

[18] Stivers, C. (1990). The public agency as polis: Active citizenship in the administrative state. Administration \& society, 22(1), 86-105.

[19] Tannenbaum, R., Weschler, I., \& Massarik, F. (2013). Leadership and organization (RLE: Organizations): A behavioural science approach. Routledge.

[20] Vigoda-Gadot, E., \& Mizrahi, S. (2008). Public sector management and the democratic ethos: A 5-year study of key relationships in Israel. Journal of Public Administration Research and Theory, 18(1), 79-107.

[21] http://www.kcsfoundation.org/?page=2,63 